\title{
Pluralism in the Light of Islam
}

\author{
Mohamad Taufiq Rahman \\ UIN Sunan Gunung Djati Bandung \\ fikrakoe@uinsgd.ac.id \\ Paelani Setia \\ UIN Sunan Gunung Djati Bandung \\ setiapaelani66@gmail.com
}

\section{Suggested Citation:}

Rahman, MT and Setia, Paelani. (2021). Pluralism in the Light of Islam. Jurnal Iman dan Spiritualitas, Volume 1, Nomor 2: pp 204-210. http://dx.doi.org/10.15575/jis.v1i2.12269

\section{Article's History:}

Received 2021-04-08; Revised 2021-04-29; Accepted April 2021.

2021. journal.uinsgd.ac.id @. All rights reserved.

\begin{abstract}
Abstrak:
Kemajemukan tidak bisa dihindari, seolah-olah itu adalah takdir manusia. Tetapi manusia sendiri seringkali tidak dapat mentolerir pluralitas ini. Karena intoleransi semacam inilah perang, intimidasi, pengusiran, konflik, dan kekacauan terjadi sepanjang waktu. Padahal, kemajemukan ini merupakan fenomena yang tak terbantahkan. Kita hidup dalam kemajemukan dan kita secara aktif atau pasif terlibat dalam dan bagian dari kemajemukan ini. Kemajemukan melekat pada semua gerakan spasial kita. Oleh karena itu, penerimaan dan eksistensi dengan orang lain atau hidup berdampingan dengan asumsi kesetaraan dalam bingkai kemajemukan adalah kebutuhan yang sangat penting. Karena kemajemukan ini selayaknya menjadi alat relasi bagi manusia untuk hidup damai dengan sesamanya. Namun demikian, agama dalam kehidupan masyarakat yang sebenarnya bisa menjadi fenomena yang sepenuhnya saling bertentangan. Seperti banyak agama lain, Islam juga sering menjadi penyebab konflik. Oleh karena itu, penting untuk melihat lagi apa pandangan Islam yang sebenarnya tentang pluralisme ini langsung dari sumbernya yang sah (yaitu, Al-Qur'an dan Sunnah). Kajian analisis tekstual ini dapat dijadikan pegangan bagi para tokoh Islam yang bergulat sehari-harinya dengan permasalahan kemajemukan di berbagai level pergaulan masyarakat.
\end{abstract}

\section{Kata Kunci: analisis teks, multikulturalisme, doktrin keagamaan, penjelasan historis}

\begin{abstract}
:
Plurality is inevitable, as if it is human destiny. But humans themselves frequently could not tolerate this plurality. Because of this kind of intolerance, wars, intimidation, expulsion, conflicts, and chaos happen all the time. This plurality is an undeniable phenomenon. We live in plurality, and we are actively or passively involved in and parts of this plurality. It is inherent in and attached to all our spatial movements. Hence, acceptance and existence with others or coexistence assuming equality in pluralism are a real need. Pluralism is rightly a relation tool for humans to live peacefully with others. Nevertheless, religions, in real societal life, could be an utterly conflicting phenomenon. Like many other religions, Islam was also often to be a cause of conflict. Therefore, it is essential to see again and again what genuinely Islamic view on this pluralism is directly from its legitimate sources (i.e., the Qur'an and the Sunna).
\end{abstract}

Keywords: textual analysis, multiculturalism, religious doctrine, historical explanation

\section{INTRODUCTION}

Plurality is a phenomenon that is impossible to avoid. One of the facts is religious plurality. Humans face the reality of the existence of various religions with their respective followers (M. T. Rahman, 2018). In this pluralistic atmosphere, plus truth claims and the missionary character of each religion, make religious communities a group of people who are very vulnerable to conflicts that tend to be sanctified because in the name of religion (truth) is sacred because it is in the word of truth (Bagir, 2005). The debate about pluralism continues to this day, for example, in Indonesia after the 1998 reforms. So that many people misinterpret pluralism itself, this is proven using a textual definition of pluralism, which is that all religions are the same. We 
both worship God, both teach goodness, and we both oppose evil. Therefore, the notion of pluralism is often considered that there is no difference between adhering to one religion or another.

However, in a multicultural society, pluralism is the primary social capital of a society. Of course, this is after going through the same understanding effort not to cause controversy in every religious community. The notion of pluralism will clash with religious teachings if it is constructed directly against one religion. Each religion has different rituals. It is a form of blasphemy when sacred religious practices are combined with other religious rituals, even though they are both claimed to be holy. As M. Rasjidi, religion is a problem that cannot be negotiated, let alone change. He described religion as not (like) house or clothes that could be changed if necessary. If a person embraces belief, that belief cannot be separated from him. Based on this belief, according to Rasjidi, religious people find it difficult to speak objectively in religious matters because humans are involved. As a Muslim, for example, he was fully aware that he was involved with Islam. However, Rasjidi acknowledged that society's history is a multi-complex containing religious pluralism and various religions. It is a reality; therefore, we inevitably have to adjust ourselves by recognizing religious pluralism in Indonesian society (Rasjidi, 1977).

This context is different from modern life, where humans must face various problems such as conflicts and disintegration of life, which are thought to be caused by religion. Apart from being a multicultural society that can no longer be denied, another problem arises from fundamentalism, radicalism, and extremism, which always acts in the name of religion. As a result, although religion is not negotiable, contextually, there needs to be a complete understanding of religious life differences, namely pluralism. The term pluralism is etymologically derived from two words, namely plural and ism. Plural means more than one. The plurality can represent diversity, so plurality is a condition of objects in a society where several different groups exist, be it economic strata, ideology, faith, or ethnic background. At the same time, ism means understanding (Husaini, 2005). From this understanding, it can be understood that pluralism is an understanding that realizes a reality about the existence of plurality, diversity as a necessity and at the same time actively contributes to its significance in the context of fostering and embodying the life of the nation and state and religion (Thoha, 2005).

In the general Indonesian dictionary, pluralism is a characteristic that expresses pluralism, like the culture seen in the Indonesian nation (Setiawan, 2012). Meanwhile, religious pluralism comes from two words pluralism and religion. In Arabic, pluralism is translated as al-ta'addudiyyah al-diniyah and in English as "religious pluralism". Because this religious pluralism originates from the English language, one must use the language dictionary to define it accurately. Pluralism in the English dictionary has three meanings. First, the definition of a church is a person who holds more than one position in an ecclesiastical structure, holding one or more simultaneously, both ecclesiastical and nonecclesiastical. Second, philosophical understanding means a system of thought that recognizes the existence of more than one primary thought. The socio-political definition is a system that acknowledges the coexistence of group diversity, whether racial, ethnic, sectarian, or party-style, while still upholding the very characteristic difference aspects between these groups. These three definitions can be simplified into one meaning, namely, the existence of various groups or beliefs at one time while maintaining the differences and characteristics of each (John-Steiner, 1995). John Hick explains that pluralism is the antithetical religious attitude of exclusivism. Exclusivism is a view that only his beliefs are the most correct; others are not. For example, the Catholic church doctrine reads Extra Ecclesia Nulla Salus, which means that outside the church there is no salvation (Eliade, 1987).

In comparison, exclusivity is a view that my religion and yours are true even though the formality is different. Other faiths are considered reasonable in the category of truth in my faith, for example, Karl Rahner's view that every Christian is a universal Muslim. As exclusivism, pluralism is a view that any teaching religion that teaches true truth is considered the same as the way of salvation (Rahner \& Henkey, 1961). So, pluralism is a way of seeing and giving positive and optimistic values to diversity itself, accepting differences as an undeniable reality (Madjid, 1988). Pluralism cannot be understood simply by saying that our society is plural, diverse, consisting of various ethnicities and religions. It only illustrates the impression of fragmentation, not pluralism; pluralism should not be understood as simply "negative good," only judging from its use for getting rid of fanaticism (Arifin, 2012). Pluralism must be understood as a genuine engagement of diversity within the bond of civility. Even pluralism is also a necessity for the safety of humankind, among others, through a supervisory mechanism and is a manifestation of God's abundant generosity to humanity (Rachman, 2010). According to Alwi Shihab, the attitude of pluralism is very encouraging in the context of dialogue to create harmony between religious communities; there are several concepts of pluralism put forward by Alwi Shihab: First, pluralism is not only pluralism alone but involves oneself (active involvement) towards diversity itself, pluralism can be seen in various places, markets, offices, schools, and others. Second, pluralism must be distinguished from cosmopolitanism. Cosmopolitanism refers to a reality where multiple religions, races, live side by side in a location. It is an example of the city of New York; in this city, there are Jews, Christians, Muslims, Hindus, Buddhists, even people who have no religion because of the city. It is cosmopolitan, as if the world's entire population is represented here, but the interaction between religions is minimal. Third, the concept of pluralism must be distinguished from relativism; a relativist will assume that their mindset determines things related to truth or values. For example, the truth and belief that the Europeans believe that Columbus discovered America is as true as the original inhabitants of the continent, that Columbus annexed America. Fourth, pluralism is not syncretism, which is combining two or more teachings into one. We have encountered a mixture of beliefs or religions from long ago. For example, New Age Religion (today's religion) combines Hindu yoga, Buddhist meditation, Islamic Sufism, and Christian mysticism (Shihab, 1999). 


\section{Plural Societies}

In origin, societies were relatively homogenous racially, ethnically, and religiously (M Taufiq Rahman, 2010; Yousif, 2000). In its development, however, societies become plural or pluralistic (Smith, 1974). By the time humans became colonizers to other humans, there is pluralism. An experience of a colonial economist could be mentioned as follows: "In Burma, as in Java, probably the first thing that strikes the visitor is the medley of peoples -European, Chinese, Indian, and native. It is in the strictest sense a medley, for the mix but do not combine. Each group holds by its religion, its own culture and language, its own ideas and ways. As individuals, they meet, but only in the market place, in buying and selling" (Smith, 1974). There is also pluralism by migration. There were Jewish and Christian communities in Madina, Khaybar, Tayma', Nejd, and South Arabia during the emerging Muslim community in the Arabian Peninsula (Saunders, 2002). And there is also pluralism by slavery: Ethiopian blacks during the Prophet Muhammad Era (Toll, 1988). As a matter of fact, throughout history, the Islamic empires faced pluralism. And for this pluralism, they were able to govern many peoples of varying racial, ethnic, and linguistic backgrounds (Trimingham, 1979). Besides, by their contacts with other cultures than Arab-Islam, they found other religions. Those non-Muslims motivated by 'the desire to profit from the business, the desire to conduct missions and the desire for knowledge and its practical use' (Haddad, 1995) had given a pluralistic condition of the Islamic history (Rosyad, 2007).

In short, until early modern times, pluralism is born by colonial or by migration, by slavery, or by merely contacts. All these processes brought about a condition of pluralism, even in a simplistic way (Toll, 1988). In modern times, moreover, plural society is unavoidable. There is pluralism in every community. Engineer mentions that there was no structured society in Mecca, such as leadership and tax payment. An attempt to establish a kind of leadership by a Christian supported by Byzantium, Uthman bin Huwayrith, was a failure (Abdullah, 2017). Recently pluralism becomes more pluralistic than that before. It is signed not only by religious, ethnic, culture, and language diversities, but it is also marked by a different class, status, or different occupation, etc. (Engineer et al., 2000).

Theoretically, societies are pluralistic insofar as they exhibit two primary features to a greater or lesser degree. First, its segmentation is into corporate groups that frequently, though not necessarily, have different cultures or subcultures. Second, a social structure compartmentalized into analogous, parallel, non-complementary but distinguishable sets of institutions (Van den Berghe, 1994). Among the sets of institutions, the primary institutional system embraces kinship, education, religion, property and economy, recreation, and certain solidities (Khaldun, 2015).

Geographically, the essence of plural societies and plural states is living together, sharing a familiar territory by groups that differ from one another in different ways (Kliot \& Waterman, 2015). Thus, boundaries that separate groups and subdivide parts into discrete units (like nationalism which creates nations from peoples), be they states, autonomous regions, or administrative areas, represent the inability of the peoples in a given region to exist within a plural framework (Smith, 1974). Mechanically, a plural society is a society with different community sections living side by side but separately within the same political unit or the same system of social relation (Rex, 1959).

Every society has its system of social relations. And pluralism is one of the systems, for pluralism is "a complex of relationships between groups in a wider society." (Mazrui, 2003). An ample detail about the place of relationships in a society could be mentioned as follows: A community is an autonomous, self-perpetuating, and internally autonomous system of social relations. Such a system distinguishes a population occupying a specific territory, but society is distinct from territory or people as a system of social relations. Society is the structure of connections through which the population of members is internally organized as joint occupants of a given area. Changes in population mass or composition, or more obviously in the territory, do not directly constitute changes in the social system, although they undoubtedly affect many ways. With differences in the techniques of social relations, which constitute societies, the distinctions between pluralism, homogeneity, and heterogeneity are directly concerned (Kuper \& Smith, 1969).

During the interaction between societies, there is an unavoidable process of cultural pluralism, for every society has its own culture. Culture in terms of community, as stated by Firth: "The terms represent different facts or components in basic human situations. If, for instance, society is taken to mean an organized set of individuals with a given way of life, culture is that way of life. If society is an aggregate of social relations, culture is the content of those relations. Society emphasizes the human component, the aggregate of people, and the relations between them. Culture emphasizes the component of accumulated resources, nonmaterial as well as material, which the people inherit, employ, transmute, add to, and transmit." (Smith, 1974).

Cultural pluralism usually refers to diversities based on racial, religious, linguistic, or other ethnic attributes (Kliot \& Waterman, 2015). This cultural pluralism is again a historical fact. Furnivall tells us the story of colonization that tropical colonial societies having brought into contact two contrary principles of social life: a low system resting on religion, personal custom, and duties, and a Western system resting on reason, impersonal law, and rights (Kuper \& Smith, 1969; T. Rahman, 2013). Based on a socially pluralistic, culturally pluralistic condition mentioned above, politically it should be pluralistic (Kliot \& Waterman, 2015). Let us see what has been going on to respond to the plurality by socio-political responses. The point here is that pluralism is the discourse of making a system of social relation based on the condition of pluralism. Hence, the discourse is mainly discussed in political area, for the first. To discuss in other areas of pluralism, then, one should go to the political discourse on pluralism as an earlier stage. 


\section{The Influence of Political Pluralism}

Besides its critics, pluralism has a powerful influence in the world of nation-states. In a political sense, the concept of pluralism begins to be worldly accepted in the 1960s (Kliot \& Waterman, 2015), especially in the Western world. Since then, countries, both industrialized and developing, have come into need of the politicization of pluralism (Skinner, 1979). Because of the differences of religious, ethnic, linguistic, regional, and racial differences, they have become more salient reference points in the political process (Smock \& Smock, 1975). There is also an adjustment to the pluralism in Muslim countries recently. It is because "democracy and the political culture of pluralism, human rights, and liberal tolerance are basic products of cultural modernity." (Tibi, 2002). The concept of pluralism, among other products of cultural modernity, is seen as a challenge to Muslim countries, "their adoption posited as a sign of having successfully joined the ranks of civilized nations" (Haddad, 1995).

In Arabic-speaking countries, pluralism has been indigenized into the term ta'addud since 1980s and has become one of the buzzwords of the 1990s. So also, in other languages such as Indonesian (kemajemukan) and Malay (majmuk), the term has been indigenized. In Muslim countries, the response of pluralism is varied. Some of them see it as "antithetical to" Islam, some of them see it as "compatible with" Islam, and the rest see it as "the very essence of Islam" (Haddad, 1995). Having its success in political life, pluralism, then, is a mode of thought. The term disseminates in every single societal life: in the world of economy, in the philosophical area, in the field of theology, etc.

This political influence is evident when it is associated with the construct of religious pluralism. It means that the construction of religious pluralism is getting stronger, especially after developing a civil society that creates academic discourse. Civil society itself is another term for civil society. Cicero first put forward civil society in his political philosophy with the term civil society, which is synonymous with the state. In subsequent developments, the term civil society is understood as community organizations characterized by high volunteerism and independence in dealing with the form and an attachment to legal values agreed upon and obeyed by the community (Culla, 1999). The nature and character of civil society is a free public sphere, which means that all activities and interactions in society are not limited by differences so that people have full access to every public activity. The public has the right to carry out activities independently in expressing opinions, associating associations, gathering and publishing information to the public. Apart from the accessible public sphere, another characteristic of civil society is democratization, which can apply democratic principles to create a democratic and open society (Mas' udi, 1999).

To foster this democratization, it takes the readiness of every member of society in the form of personal awareness, equality, and independence, as well as having the intention and effort to behave democratically towards others. Civil society is also characterized as tolerant, pluralist, social justice, and has high social participation. Community participation is entirely free from manipulation, intimidation, and intervention from other parties - so that civil society has the maturity and responsible political independence while providing guarantees towards the creation of social justice and harmony amid social life (Fergusen, 2007).

Civil society is an impact of the phenomenon of modernity which was accompanied by the emergence of the wonder of the rise of world religions (the desire to re-explore religion), which at the same time also smelled of primordialism, sectarianism, and radicalism (Tibi, 2012). Religious educators and activists of socio-religious preaching are asking, why has the program of "transmission" and "conservation" of spiritual values that are so noble and valuable in various religious traditions turn into "intolerance" and "confrontation"? Why is it that in increasingly modern times, scientists are increasingly predicting a clash of civilizations? (Huntington, 2000). Is not the modern era claimed to be the most civilized era in human history? Maybe this prediction is correct, but why does violence in the name of religion appear everywhere like in Ireland, Palestine, Ambon, Poso, Karachi, Chechnya, Southern Thailand, Madrid, Casablanca, Nigeria, Riyad, or Afghanistan (Juergensmeyer, 2017). Why every time before a change of political leadership, such as in Indonesia in 1996-1998, are there riots worrying for life together? (Mas' oed et al., 2001). Why are Bombs detonated in various places? In Indonesia, there were bomb explosions in Bali (Legian of Kuta), Jakarta (Marriot Hotel of Kuningan), and in several other areas such as Poso, Ambon, and others.

The dynamics of democratization and disintegration problems must be resolved by understanding and transferring knowledge about pluralism. There is no antidote to dealing with the discourse of postmodernism conflict other than pluralism and religious plurality. Religious pluralism aims to create a process of humanization that focuses on the formation of social beings with moral autonomy, psychological sensitivity, and cultural sovereignty to manage conflicts, respect diversity, and understand and find solutions to cross-cultural problems.

\section{DISCUSSION \\ Pluralism in Islam}

Concerning the attitude of Muslims towards the phenomenon of pluralism, Muslims are divided into two factions, namely those who reject and accept the phenomenon of pluralism. For those who refuse to be motivated by several perceptions, first, pluralism is recognized as sunnatullah (the Law of God), but is considered a threat to faith that will weaken faith. Second, pluralism is considered as a threat to identity, where the rationale is because in plurality, absolute truth is replaced by relative truth, so that it is considered that truth is no longer singular but plural, even though the people think that the religion recognized by Allah is only Islam. Third, pluralism creates a threat to religion because it is feared that there will be religious syncretism that will give birth to a public faith that combines the teachings of all religions (Rahardjo, 2010). 
Syed Hasyim Alim, former Chancellor of the Aligarh University of India, said that pluralism is a condition of society where various ethnicities, religions, and cultures live peacefully side by side in one nation (Pradhan \& Visweswaran, 2011). From this definition, the question arises whether Islam denies the spirit of pluralism to be able to live peacefully side by side with one another with different religious, cultural, and ethnic backgrounds? And there are many more questions, especially about Islam in this phenomenon of religious pluralism. As is pluralism described in the Koran? And how does Islam view pluralism? If we look closely, the values of pluralism are explained a lot in the Koran. It seems that the Koran is very confident and, at the same time, declares itself as a religion that is open to differences and plurality-starting from the verse which talks about the position of humans who are admired in Islam. Something to be noted for the first time is that Islam precisely respects the part of all humans. God confirms this by saying that: "We have honored the sons of Adam..." (QS. 17: 70). Hence, there is no hierarchy of humans that one man is above another man. In Islam, all are equals, equals in honor.

The next verse that scholars regarding pluralism often quote is about the diversity that is told in the Koran. In the life of all complexities of nations, tribes, groups, races, and others (Zulaeha, 2020), Islam promotes mutual interaction beginning with knowing each other (lita'ârafû): "O mankind! We created you from a single (pair) of a male and a female, and made you into nations and tribes, that he may know each other (not that ye may despise each other). Verily the most honored of you in the sight of Allah is (he who is) the most righteous of you...." (QS. 49: 13). Here it is that from the beginning Islam admits the existence of plurality among mankind without any hierarchy. Even the Qur'an itself is not guidance exclusively for Muslims. The Qur'an calls himself as guidance for all humans, without exception: "Ramadan is the (month) in which was sent down the Qur'an, as a guide to mankind, also clear (Signs) for guidance and judgment..." (QS. 2: 185). Therefore, those who have had the guidance (Muslims) are mandated to tell the guide to others: "Ye are the best of peoples, evolved for mankind. Enjoining what is right, forbidding what is wrong, and believing in Allah ..." (QS. 3: 110).

In the plurality of humans, it is undeniable that there are conflicts between parties to others. One that causing conflict is truth claim. In Islam, claiming truth is forbidden, for it leads to vanity: "Therefore hold not yourselves purified: He knows best who it is that guards against evil." (QS. 53: 32). It is also noteworthy that in the dynamics of pluralistic life the proposal of Islam is not a system of destructive rivalry, but constructive competition: "If Allah had so willed, He would have made you a single people, but (His plan is) to test you in what He hath given you: so strive as in a race in all virtues ..." (QS. 5: 48). The above Qur'anic principles are actually and practically exemplified by the Prophet (p.b.u.h.) in his societal life. Among others, he made a declaration of tolerance to the plural society of Medina, by making the Medina Charter, a common and shared declaration of Medinan citizens to preserve security and toleration each other. In another occasion, he did not respond ethnocentrically (that it is his group which is superior and that others are inferiors) to the infidels who insulted and sometimes threw him when they were preached by him. On the contrary, he always gave them the prayers so that they have the guide of God (Zulaiha, 2017).

And about the plural humanity, he had upheld the foundation of plurality by his sermon on his farewell pilgrimage (Hajj Wada '): "... the Arabs are not higher than those Non-Arabs (Ajam) and that Non-Arabs are not higher than the Arabs. All of you are the sons of Adam and Adam is created from the soil ... Bleeding enemy happened during the age of lgnorance (Jâhiliyah) has been forbidden... Your slaves, you should feed them as you feed yourselves and give them clothes as you wear ..." (Narrated by Muslim, Chapter Hajj Wada '). That is the Prophet's pluralism, Islamic pluralism, the pluralism willing to the equality of humans, even in the end of the above Tradition (Hadith), the Prophet eagerly wants to humanize humans (humanization) between those who are in the gap by their economic condition, or other condition (Wibisono, 2020).

In responding to sunnatullah, which means a necessity that has been outlined by Allah, we should be able to maintain this plurality as a good goal to maintain a harmonious situation between the differences that exist because Islam is a religion of rahmatan lil alamin. It is impossible to achieve this without an attitude of mutual understanding, understanding and tolerance of others towards existing differences. It is hoped that with this tolerance, mutual understanding can be created to avoid conflict with each other, a society that loves peace and strengthens each other's ukhuwah (unity). Thus, the existence of religious pluralism is clearly acceptable to Islam. The Qur'an exactly says that, "Let there be no compulsion in religion" (QS. 2: 256). Hence, in Islam, there is religious freedom which is one of the human rights.

As tolerant as may be, the Prophet had ever got angry with one of his companions insulting those who worship idols. His reason is that if we insult their idols, they would insult back our God. It was to this event that a verse of the Qur'an revealed. This verse says that: "Revile not ye those whom they call upon besides Allah, lest they out of spite revile Allah in their ignorance." (QS. 6: 108). Besides, the Prophet also says, "Whoever disturbs the dhimmi (non-Muslim minority), he disturbs me". Such saying shows that how big it was the responsibility of the Prophet to the security of non-Muslims living under the Muslim reign. Islam, then, respects the existence of other religions. It is told in the Qur'an that those who believe (in the Qur'an) and those who follow the Jewish (scriptures), and the Christians and the Sabians, any who believe in Allah and the Last Day, and work righteousness, shall have their reward with their Lord on them shall be no fear, nor shall they grieve (QS. 2: 62). In short, in the tribute to the religious plurality, the Qur'an proportionally places the plurality into the emulation in virtue and piety (istibaq al-khairât) (QS. 5: 48).

\section{Cosmological Pluralism}

Besides revering human pluralism and religious pluralism as a part of Islam itself, Islam has also its doctrines on cosmological pluralism. That is, the project placing the cosmic into its place. It means that the cosmological order (sunnah Allah) should uphold its stability. Hence, it not only cares of human plurality, but it also could bless all entire cosmic without 
recognizing any differences between the creatures of God (Riyani \& Huriani, 2017). Here it is the one should be reached by the Muslims as a goal of struggle. It is because that far before today, the Prophet had placed himself to be a Mercy for all creatures (rahmah li al-'Âlamîn) (QS. 21: 107). His concrete example is that his warning to his soldiers departing for wars: "Do not kill women, children, and elderly people. Do not destruct date palms, do not pull out trees, and do not ruin houses." (AlHadith). It is the whole explanation on pluralism based on Islamic normative viewpoint. It is clear that Islam highly appreciates plurality as a blessing from God, so that it is highly recommended to embrace the idea of pluralism.

By this spirit of pluralism, it would be assured that religious pluralism would be manifested and that the advancement of society would be in a way of success. To the further idea, by this determination of pluralism would create a general humanizing humans and a cosmological, universal order. Here it is the genuine of our duty as the leaders of the Earth (Khalifah fi al-Ardli).

\section{CONCLUSION}

The pros and cons of religious pluralism continue to emerge among academics today. Especially those who are contra always view with a narrow angle that pluralism will destroy the essential values of religion. As a result, there is a misperception about what is the focus of discussion of pluralism. Pluralism certainly does not aim to unite all religions into one religion or one teaching as is the case with the New Age Religion movement in the West. In addition, conflicts and violence in the name of religion, including Islam, often threaten democratic life and tarnish the peace initiated by all religions in the contemporary era. Whereas Islam is a religion that accommodates pluralism and makes it a pillar of life. In Islam, pluralism is widely discussed in the holy verses of the Koran. Therefore, the Koran talks a lot about tolerance, human rights, multicultural society, to cosmological life. In fact, the idea of Islamic pluralism is also supported by the spirit of creating a civil society initiated by the noble Prophet Muhammad. Unfortunately, modern life has caused many Muslims to flee from the spirit of Islam in building a pluralistic society, so that many are trapped in radical and extreme behaviors. This should be our homework together, rather than still debating and questioning pluralism textually.

\section{BIBLIOGRAPHY}

Abdullah, S. R. (2017). Tujuan Negara dalam Islam Menurut Yusuf al-Qaradhawi. The Objectives of Islamic State According to Yusuf Al-Qaradawi]. Asy-Syari'ah, 19(1), 15-36.

Bagir, Z. A. (2005). Integrasi IImu dan Agama: Interpretasi dan Aksi. Mizan Pustaka.

Culla, A. S. (1999). Masyarakat madani: pemikiran, teori, dan relevansinya dengan cita-cita reformasi. RajaGrafindo Persada. Engineer, A. A., Mutaqin, I., \& Kamdani. (2000). Devolusi Negara Islam. Pustaka Pelajar.

Haddad, Y. Y. (1995). Islamists and the Challenge of Pluralism. Center for Contemporary Arab Studies and Center for MuslimChristian.

Husaini, A. (2005). Pluralisme Agama. Jakarta: Pustaka Al-Kautsar.

Juergensmeyer, M. (2017). Terror in the mind of God: The global rise of religious violence (Vol. 13). Univ of California Press. Khaldun, I. (2015). The Muqaddimah: An Introduction to History-Abridged Edition. Princeton University Press.

Kliot, N., \& Waterman, S. (2015). Pluralism and political geography: people, territory and state. Routledge.

Kuper, L., \& Smith, M. G. (1969). Pluralism in Africa. Berkeley: University of California Press.

Mas' udi, W. (1999). Masyarakat madani: visi etis Islam tentang civil society. Jurnal Ilmu Sosial Dan Politik, 3(1999).

Mazrui, A. (2003). Conflict in Africa: an overview. Armed Conflict in Africa, 21-42.

Pradhan, R., \& Visweswaran, K. (2011). Ethnicity, caste and a pluralist society. Perspectives on Modern South Asia: A Reader in Culture, History, and Representation, 100.

Rahman, M. T. (2018). Pengantar filsafat sosial. Lekkas.

Rahman, M Taufiq. (2010). Pluralisme Politik. WAWASAN: Jurnal IImiah Agama Dan Sosial Budaya, 34(1), 1-13.

Rahman, T. (2013). 'Indianization'of Indonesia in an Historical Sketch. International Journal of Nusantara Islam, 1(2), 56-64.

Rasjidi, M. (1977). Koreksi Terhadap Drs. Nurcholis Madjid Tentang Sekularisasi. Bulan Bintang.

Rex, J. (1959). The plural society in sociological theory. The British Journal of Sociology, 10(2), 114-124.

Riyani, I., \& Huriani, Y. (2017). Reinterpretasi Asbāb Al-Nuzūl bagi Penafsiran Alquran. Wawasan: Jurnal Ilmiah Agama Dan Sosial Budaya, 2(1), 113-130.

Rosyad, R. (2007). A quest for true Islam: A study of the Islamic resurgence movement among the youth in Bandung, Indonesia. ANU Press.

Saunders, J. J. (2002). A history of medieval Islam. Routledge.

Skinner, M. (1979). David R. Smock and Audrey C. Smock, The Politics of Pluralism: A Comparative Study of Lebanon and Ghana (New York: Elsevier Scientific Publishing Company, Inc. 1975). Pp. 369. International Journal of Middle East Studies, 10(2), 280-281.

Smith, M. G. (1974). The plural society in the British West Indies. Univ of California Press.

Smock, D. R., \& Smock, A. C. (1975). The politics of pluralism: A comparative study of Lebanon and Ghana. Elsevier New York.

Thoha, A. M. (2005). Tren pluralisme agama: tinjauan kritis. Gema Insani.

Tibi, B. (2002). The challenge of fundamentalism: Political Islam and the new world disorder. Univ of California Press.

Toll, C. (1988). The Purpose of Islamic Studies. Islam: State and Society, 13-25. 
Trimingham, J. S. (1979). Christianity among the Arabs in pre-Islamic times.

Van den Berghe, P. L. (1994). The quest for the other: ethnic tourism in San Cristóbal, Mexico. University of Washington Press. Wibisono, M. Y. (2020). Sosiologi Agama. Prodi P2 Studi Agama-Agama UIN Sunan Gunung Djati Bandung.

Yousif, A. (2000). Islam, minorities and religious freedom: A challenge to modern theory of pluralism. Journal of Muslim Minority Affairs, 20(1), 29-41.

Zulaeha, E. (2020). Prinsip Liberalisme dalam Metodologi Tafsir Feminis: Pembacaan pada Karya-karya Husein Muhammad. Khazanah: Jurnal Studi Islam Dan Humaniora, 18(1), 25-48.

Zulaiha, E. (2017). Tafsir Kontemporer: Metodologi, Paradigma dan Standar Validitasnya. Wawasan: Jurnal Ilmiah Agama Dan Sosial Budaya, 2(1). conditions of the Creative Commons Attribution (CC BY SA) license (http://creativecommons.org/licenses/by-sa/4.0/). 